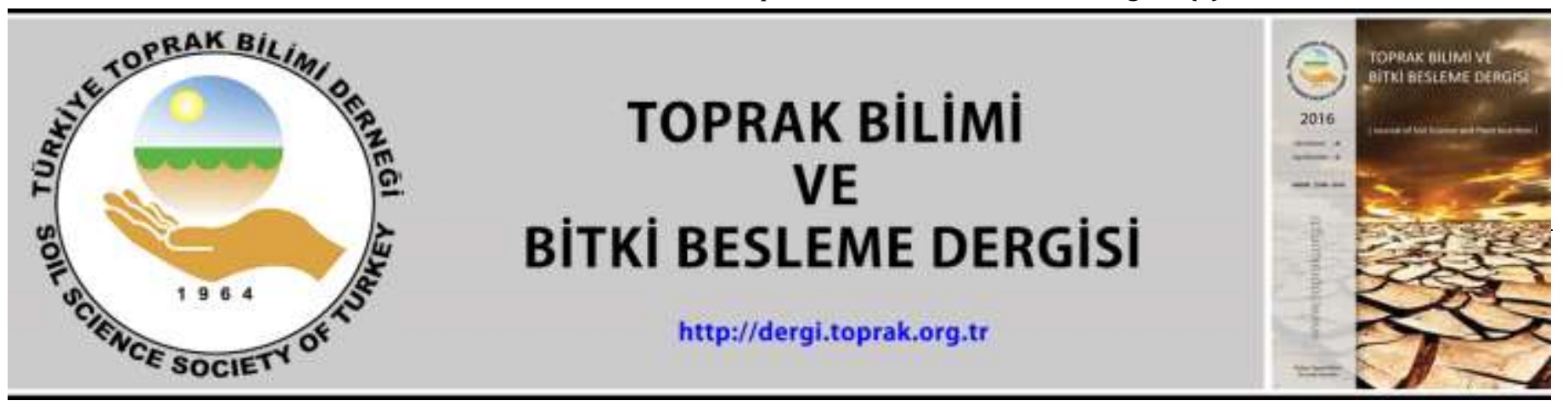

\title{
Farklı sulama miktarlarında yetiştirilen buğday bitkisinin su kullanma randımanı ile verimlilik parametreleri arasındaki ilişkiler
}

\author{
Coşkun Gülser *, $\odot$ Rıdvan Kızılkaya
}

Ondokuz Mayıs Üniversitesi, Ziraat Fakültesi, Toprak Bilimi ve Bitki Besleme Bölümü, Samsun

\begin{abstract}
Özet
$\mathrm{Bu}$ çalışmada bitkiye yarayıșlı su kapasitesinin \%25, \%50 ve \%100'ündeki sulama koşullarında yetiștirilen buğday bitkisinin su kullanma randımanı (SKR), incelenen büyüme ve verim parametreleri arasındaki ilişkiler araștırılmıştır. Bitkiye uygulanan toplam sulama suyu miktarı 378 mm'den (\%100 BYS) 286 mm (\%50 BYS) ve 249 mm'ye (\%25) düștükçe bitki boyu \%14,5 ve \%23.0, toplam biyokütle $\% 37,3$ ve $\% 56,1$, dane verimi $\% 31,5$ ve $\% 53,3$ oranlarında azalmıştır. Toplam biyokütle ve dane verimi için hesaplanan en yüksek SKR değerleri sırasıyla 1,49 g/L ve 0,67 g/L olarak \%100 BYS da bulunurken, aynı parametreler için en düşük SKR değerleri sırasıyla 0,99 g/L ve 0,47 g/L olarak \%25 BYS uygulamasında bulunmuştur. Sulama suyu miktarı, SKR ve bitki gelişim parametreleri ile önemli pozitif, transprasyon oranı ve hasat indeksiyle önemli negatif ilişki vermiştir. SKR değerleri bitki boyu, başak boyu, toplam biyokütle, dane verimi ve 1000 dane ağırlı̆̆ıla çok önemli pozitif, transprasyon oranı ve hasat indeksi değerleriyle negatif ilişkiler göstermiştir. Sonuç olarak toprak nem düzeyinin bitki gelişimi için önemli bir faktör olduğu ve aynı zamanda toprak nem miktarının azalmasıyla fotosentez oranın düşmesine bağlı olarak SKR, bitki gelişimi ve verim değerlerinin azaldığı belirlenmiştir.
\end{abstract}

Anahtar Kelimeler: Buğday, sulama, su kullanma randımanı, transprasyon oranı, verim parametreleri.

\section{Relationships between water use efficiency and yield parameters of wheat grown in different irrigation amounts}

\begin{abstract}
In this study, the relationships among water use efficiency (WUE), growth and yield parameters of wheat grown under irrigation conditions at $25 \%, 50 \%$ and $100 \%$ of available water capacity were investigated. While the amount of total irrigation water reduced from $378 \mathrm{~mm}(100 \%$ AWC) to $286 \mathrm{~mm}$ (50\% AWC) and $249 \mathrm{~mm}$ (25\%AWC), the plant parameter values decreased as 14,5\% and $23.0 \%$ in plant height, $37,3 \%$ and $56,1 \%$ in total biomass, $31,5 \%$ and $53,3 \%$ in grain yield, respectively. While the highest WUE value for total biomass $(1,49 \mathrm{~g} / \mathrm{L})$ and grain yield $(0,67 \mathrm{~g} / \mathrm{L})$ was obtained with $100 \%$ AWC application, the lowest WUE value for the same parameters was found as $0,99 \mathrm{~g} / \mathrm{L}$ and $0,47 \mathrm{~g} / \mathrm{L}$ with $25 \%$ WUE application, respectively. Irrigation water amount gave significant positive relationships with WUE and plant growth parameters while it gave significant negative relationships with transpiration ratio and harvest index. The WUE values showed significant positive relationships with plant height, spike height, total biomass, grain yield, 1000 grain weight, and significant negative relationships with transpiration ratio, harvest index values. As a result, it was determined that soil moisture level is an important factor for plant growth, and also WUE, plant growth and yield values decrease with reducing photosynthesis rate due to decreasing soil moisture amount.

Keywords: Wheat, irrigation, water use efficiency, transpiration ratio, yield parameters.
\end{abstract}

(C) 2020 Türkiye Toprak Bilimi Derneği. Her Hakkı Saklıdır

\section{Giriş}

Kuraklık stresi bitki gelişimi üzerinde etkili olan en önemli abiyotik faktörlerden birisidir. Kuraklık stresi bitkilerde sadece büyüme ve gelişmeyi etkilemekle kalmayıp aynı zamanda verim miktarlarının da önemli düzeyde azalmasına neden olur (Pan ve ark., 2002). Dünya genelinde gelişmekte olan ülkelerin büyük çoğunluğunu tehdit eden su stresi yüksek verim alımını sınırlandıran bir faktör olarak genellikle \% 37'lik bir oran ile yetersiz sulama koşullarına sahip buğday yetiștiriciliği yapılan yarı kurak alanlarda görülmektedir (Rajaram, 2001). Su stresi sadece bitkilerin morfolojisi üzerinde etkili olmaz, aynı zamanda onların metabolizmalarını da etkiler. Buğday bitkisinin gelişme döneminde görülen su stresinin biyokütleyi,

\section{* Sorumlu yazar:}

Tel. : : 03623121919

E-posta : cgulser@omu.edu.tr
Geliș Tarihi

Kabul Tarihi
e-ISSN

DOI : $10.33409 /$ tbbbd.757010 
kardeșlenmeyi, tane büyüklüğü ve ağırlığını azalttığı bilinmektedir (Dencic ve ark., 2000; Gupta ve ark., 2001). Güler (2001) ekmeklik buğdayın su stresine karşı kalite özelliklerindeki değișimi araştırdığı çalışmasında, en yüksek kalite değerlerini su stresi olmayan uygulamalarda, en düşük değerleri ise tüm gelişme dönemlerinde su stresi olan uygulamalardan elde ettiğini bildirmiştir. Balkan ve Gençtan (2013), buğdayda su kullanımını sınırlandıran osmotik stresin artmasıyla çimlenme oranının, kök uzunluğunun, fide boyunun, kök yaş ağırlığının, toprak üstü yaş ve kuru ağırlığının önemli düzeyde azaldığını, ortalama çimlenme süresi ve kök kuru ağırlığının ise önemli düzeyde arttığını bildirmişlerdir. Öztürk (1999), buğday bitkisinde kuraklığın sulu koşullara göre birim alandaki dane sayısını, ağırlığını ve verimi önemli düzeyde azalttığını bildirmiştir.

Buğday bitkisinin farklı gelişme dönemlerindeki kuraklık koşulları ve çeşide bağlı olarak verim ve verim unsurlarında önemli düzeyde azalma gösterdiği bilinmektedir (Moustafa, 1996; Saleem, 2003; Maqbool ve ark., 2015). Sivamani ve ark. (2000) genetiği değiștirilmiș buğday hatlarına ait verim parametrelerinin kuraklığa karşı iyi dayanım gösterdiğini bulmuşlardır. El Hafid ve ark. (1998), faklı yazlık buğday çeşitleri ile arazi ve serada yürüttükleri çalışmada, farklı kuraklık koşulları altında yetişen buğday bitkisinin su kullanma randımanı, toplam kuru madde ve verim değerlerinin önemli düzeyde farklılıklar gösterdiğini belirtmişlerdir. Blum (1993) kuraklık koşullarına dayanım ile ilgili yapılan çalışmalarda, toplam biyokütle verimi ile su kullanma randımanı değerlerinin, dikkate alınması gereken en önemli agronomik parametrelerden olduğunu bildirmiştir. Toprağın su tutma kapasitesi toprak kalitesinin önemli bir göstergesidir ve bitkiler toprakta 1/3 atm'de tarla kapasitesi ile $15 \mathrm{~atm}$ 'de solma noktası arasında tutulan ve bitkiye yarayışlı nem kapasitesi olarak adlandırılan nem değerinden faydalanabilmektedirler (Candemir ve Gülser, 2011; Demir ve Gülser, 2015; Gülser ve ark., 2015). Bu çalışmada bitkiye yarayışlı nem kapasitesindeki nem değerinin farklı düzeylerinde yapılan sulama suyu miktarlarının buğday bitkisinin gelişimi üzerindeki etkisi araştırılmıştır. Bu amaç doğrultusunda bitkiye yarayışlı su kapasitesinin \%25, \%50 ve tamamının (\%100) sağlandığı sera denemesinde, farklı su stres koşullarında yetiştirilen buğday bitkisinin su kullanma randımanı, büyüme ve verim parametrelerine ait değişimler ve aralarındaki ilişkiler araştırılmıştır.

\section{Materyal ve Yöntem}

Deneme Ondokuz Mayıs Üniversitesi Ziraat Fakültesi Toprak Bilimi ve Bitki Besleme Bölümüne ait serada tesadüf parselleri deneme desenine göre kurulmuştur. Sera denemesinde Pandas yazlık buğday çeşidi bitkiye yarayışlı su kapasitesinin üç faklı düzeyinde (\%25, \%50 ve \%100) 10 tekrarlamalı olarak yetiştirilmiştir. Buğday tohumları 20 adet olacak şekilde $18 \mathrm{~cm}$ çapındaki $5 \mathrm{~kg}$ 'lık saksılarda 4,5 kg firın kuru

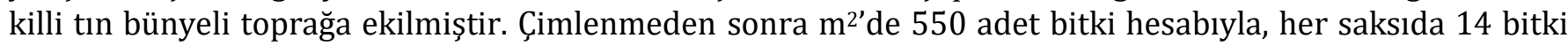
kalacak şekilde seyreltme yapılmıştır. Kardeşlenme döneminden önce her saksıya $100 \mathrm{ml}$ Hoagland besin çözeltisi verilmiş ve başka gübreleme yapılmamıștır. Denemede kullanılan killi tın bünyeli toprağın bitkiye yarayışlı su (BYS) kapasitesi \%15,05 olarak hesaplanmıştır (Çizelge 1). Bu değer dikkate alınarak saksıların nem içeriği BYS'un \%100, \%50 ve \%25 sulama uygulamaları için sırasılyla \%27,15, \%19,62 ve \%15,86 nem içeriğine getirilmiştir. Saksılar hasat anına kadar iki gün arayla tartılarak eksilen su miktarları BYS kapasitesinin $\% 25, \% 50$ ve \%100'üne atmosferik yağışlardan hasat edilen ve filtreden geçirilen suyla sulanarak tamamlanmıştır. Deneme sonunda bitki su tüketimine bağlı olarak uygulanan toplam sulama suyu miktarları her bir saksı için hesaplanmıştır. Bitkiler 93 günlük gelişme dönemi sonunda başak oluşturup tam olgunluğa eriștiklerinde toprak yüzeyinden kesilerek hasat edilmiștir. Hasat öncesi her saksıdaki bitki boyları ve başak uzunlukları ölçülerek kayıt edilmiştir. Hasat sonrası her bir saksıdaki toplam kuru bitki ağırlığı (biyokütle) ve dane ağırlıkları belirlenmiş ve daha sonra 1000 dane ağırlığı ve dane veriminin toplam biyokütle verimine oranı şeklinde ifade edilen hasat indeksi (Hi) değerleri hesaplanmıştır (Budak ve Yıldırım, 1995). Toplam verimin bitki gelişme dönemi boyunca harcanan toplam su miktarına oranlanması ile belirlenen su kullanma randımanı (SKR) değerleri toplam biyokütle ve dane verimleri için ayrı ayrı hesaplanmıştır.

Denemede kullanılan toprak örneğine ait bünye, tarla kapasitesi ve solma noktası analizleri Demiralay (1993)'ın belirttiği yöntemler esas alınarak ve pH, EC, kireç, toplam azot ve organik madde analizleri ise Kacar (1994)'ın belirttiği yöntemler esas alınarak yapılmıştır (Çizelge 1). Analiz sonuçlarına göre toprak örneğinin killi tın bünyeli, nötr reaksiyonlu, tuzsuz, kireçli ve organik maddece düşük seviyede olduğu belirlenmiştir (Soil Survey Staff, 1993).

Denemeden elde edilen verilere ait varyans analizleri tesadüf parselleri deneme desenine göre SPSS 17 programında yapılmış, ortalamalar arasındaki farkların önem düzeyi Duncan çoklu karşılaştırma testi ile 
belirlenmiştir. Denemede ölçülen ve hesaplanan değerler arasındaki korelasyon katsayıları da belirlenmiştir (Yurtsever 1984).

Çizelge 1. Denemede kullanılan toprağa ait bazı fiziksel ve kimyasal özellikler

\begin{tabular}{lllr}
\hline Kum, \% & 28,55 & $\mathrm{pH}(1: 1)$ & 7,25 \\
Kil, \% & 30,16 & $\mathrm{EC}_{25}, \mathrm{dSm}^{-1}$ & 0,50 \\
Silt, \% & 41,29 & $\mathrm{CaCO}_{3}, \%$ & 12,84 \\
Tarla Kapasitesi, \% & 27,15 & Toplam N, \% & 0,11 \\
Solma Noktası, \% & 12,10 & Organik Madde, \% & 2,01 \\
Bitkiye Yarayışlı Su Kapasitesi, \% & 15,05 & $\mathrm{C} / \mathrm{N}$ & 10,54 \\
\hline
\end{tabular}

\section{Bulgular ve Tartıșma}

\section{Sulama Suyu Miktarının Bitki Gelişimine ve Verime Etkisi}

Sera denemesinde 93 günlük gelişme periyodu boyunca bitkiye yarayışlı su kapasitesinin üç farklı düzeyinde (\%25, \%50 ve \% 100 BYS) uygulanan toplam sulama suyu miktarlarına ait ortalama değerler Şekil 1'de verilmiștir. Sera koșullarında bitkiye yarayıșlı su kapasitesinin \%100, \%50 ve \%25'inin sağlandığı uygulamalarda, gelişme dönemi boyunca verilen sulama suyu miktarlarının toplam bitki su tüketimlerine bağlı olarak sırasıyla $378 \mathrm{~mm}, 286 \mathrm{~mm}$ ve $249 \mathrm{~mm}$ olduğu ölçülmüştür. Toplam sulama suyu miktarları istatistiksel olarak kendi aralarında önemli düzeyde farklılık göstermiştir $(\mathrm{P}<0.01)$. Uygulamalar arasında verilen toplam su miktarlarının farklı olmasına rağmen, bütün uygulamalarda yazlık buğday bitkisinin su tüketimi veya evapotransprasyon değerinin 15. günden 71. güne kadar daha hızlı arttığı, bu tarihten sonra azaldığı gözlenmiștir. Kardeșlenme döneminden dane dolum süresine kadar buğday bitkisinin su tüketimi artmakta, fizyolojik olgunlaşma sonu ve hasat dönemine kadar olan sürede ise bitki su tüketimi giderek azalmaktadır. Öztürk ve Korkut (2018) sapa kalkma döneminden başaklanma dönemine kadar oluşan erken dönem kuraklığın, başaklanma döneminden sonraki kuraklığa göre verimi daha fazla etkilediğini bildirmişlerdir. Bu çalışmada da bitkilerin başaklanma dönemine kadar tükettikleri su miktarının daha fazla olduğu görülmektedir (Şekil 1).

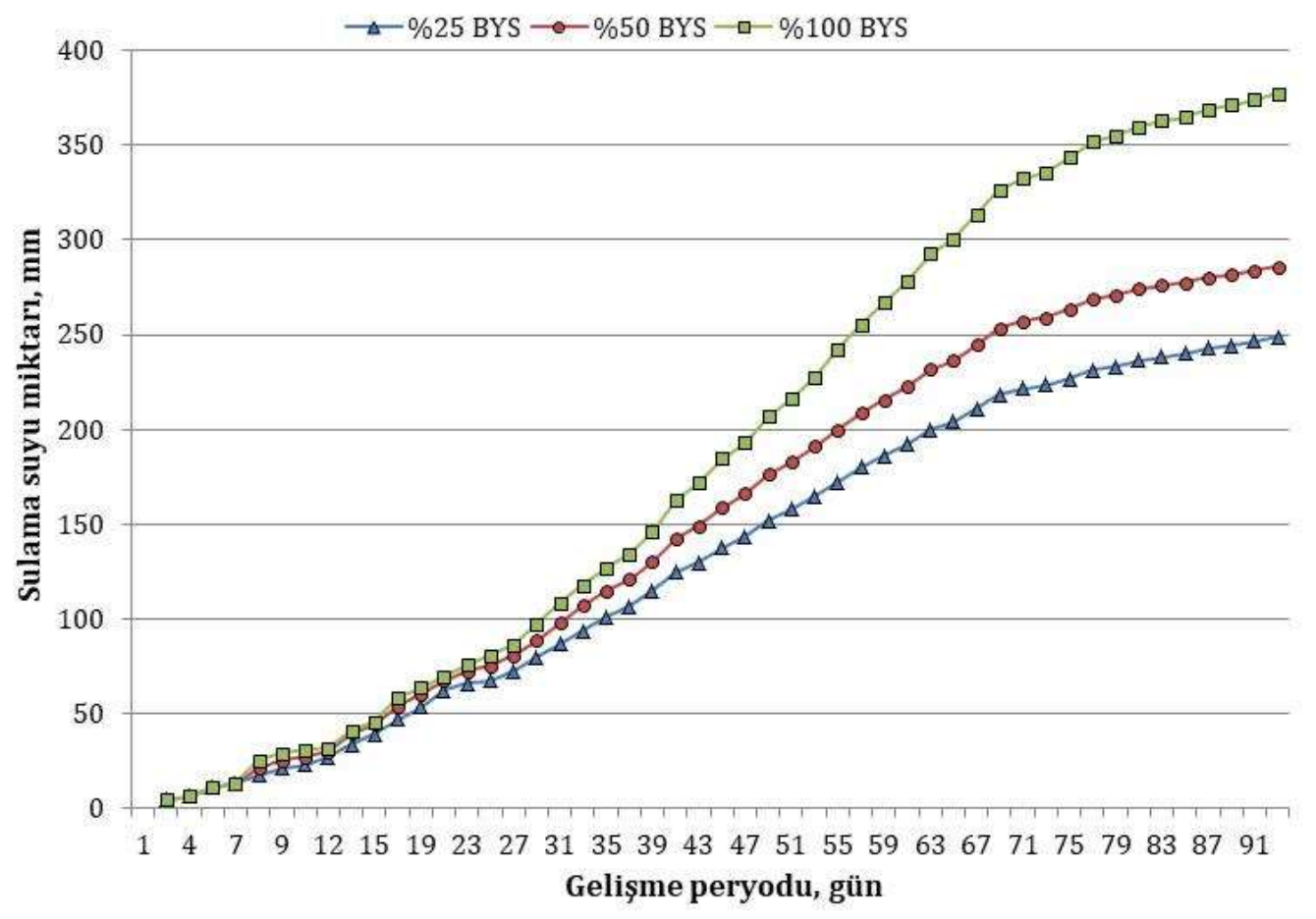

Şekil 1. Bitkiye yarayıșlı suyun (BYS) farkı düzeylerinde uygulanan toplam sulama suyu miktarları.

Bitkiye yarayışlı suyun farklı düzeylerindeki uygulamalara ait bitki büyüme ve gelişim parametreleri ile verim değerleri Çizelge 2'de verilmiştir. Bitki ve başak boyları BYS'un her üç uygulamasında da istatistiksel olarak önemli düzeyde farlılık göstermiştir ( $\mathrm{P}<0.01)$. Sulamanın tam yapıldığı \%100 BYS uygulamasında en uzun bitki boyu $(61,91 \mathrm{~cm})$ ve başak boyu $(8,84 \mathrm{~cm})$ değerleri elde edilirken, en kısa bitki boyu $(47,64 \mathrm{~cm})$ ve bașak boyu $(7,68 \mathrm{~cm})$ değerleri en az sulama yapılan \%25 BYS uygulamasında belirlenmiștir. Sulamanın tam yapıldığı \%100 BYS uygulamasıyla karşılaştırıldığında, \%50 ve \%25 BYS uygulamalarında sırasıyla bitki 
boyları \%14,5 ve \%23.0, başak boyları ise \%2,5 ve \%13,1 oranlarında azalma göstermiştir. Nitekim, Ünsal ve ark. (2018) tam ve yarı sulama uygulamalarında yetiștirilen buğday bitkilerinin boylarında kuraklık koşuluna bağlı olarak 48,4 cm ile 59,7 cm arasında değişim gösterdiğini bildirmiş olması bizim sonuçlarımızı destekler niteliktedir. Ayrıca yine Arnon (1972) stres koşullarındaki bitkilerin boylarındaki kısalmayı, bitki dokularındaki nispi su doygunluğunun (turgidite) azalması ve protoplazmadaki dehidrasyon artışı sonucunda turgor ve hücre genişlemesindeki azalmayla birlikte hücre bölünmesinde görülen düşüşle açıklamıştır. Saleem (2003) farklı ekmeklik buğday çeşitleri ile sulamalı ve sulamasız arazi koşullarında yürüttüğü çalışmada, sulu koşullarda yetişen buğday bitkilerinin boy, başak uzunluğu toplam verim, dane verimi ve 1000 dane ağırlıklarının kurak koşullarda yetişenlerden istatistiksel olarak önemli düzeyde daha yüksek olduğunu bulmuştur.

Farklı sulama suyu miktarlarındaki bitki gelişimine bağlı olarak buğday bitkisinin verim parametrelerinde de istatistiksel olarak önemli düzeyde farklılıklar belirlenmiștir (Çizelge 2). Toplam biyokütle, dane verimi ve 1000 dane ağırlığına ait en yüksek değerler \%100 BYS uygulamasında belirlenirken, en düşük değerler ise en az sulama suyu miktarına sahip \%25 BYS uygulamasında bulunmuştur. Su stresinin olmadığı \%100 BYS uygulamasıyla karșılaștırıldığında, $\% 50$ ve \%25 BYS uygulamalarında sırasıyla toplam biyokütle \%37,3 ve $\% 56,1$, dane verimi $\% 31,5$ ve $\% 53,3$, bitkilerin 1000 dane ağırlıkları ise $\% 7,5$ ve $\% 14,2$ oranlarında azalmıştır. Kurak koşullarda yetiştirilen buğday bitkisinin kuru ağırlığında azalma, sapların daha kısa ve başakların daha küçük olduğu, dane veriminin önemli düzeyde düştüğü bilinmektedir (Majer ve ark., 2008). Öztürk (1999) buğday bitkisinde tam kuraklığın sulu koşullara göre dane verimini \%65,0 ve dane ağırlığını \%19,9 oranlarında azalttığını bildirmiştir.

Bitkilere ait hasat indeksi değerleri incelendiğinde en yüksek değerin $(\% 49,19) \quad \% 50$ BYS uygulamasında belirlenmiş, fakat bu değer \%100 BYS uygulamasındaki hasat indeksi değerinden $(\% 47,89)$ istatistiksel olarak önemli düzeyde bir farklılık göstermemiştir. Austin (1994) kuraklık koşullarında yetişen buğday bitkilerindeki yüksek hasat indeksi değerlerini, bitkinin kuraklığa dayanım için besin elementlerini genç sürgünlere sağlayarak boyunu daha kısa tutmasıyla açıklamıştır. Bu çalışmada da benzer nedenle \%50 BYS uygulamasında, \%100 BYS uygulamasına göre hasat indeksi değeri artış göstermiş olabilir. En az sulama suyuna sahip \%25 BYS uygulamasında en düşük hasat indeksi değeri $(\% 45,04)$ elde edilmiş ve bu değer istatistiksel olarak diğer uygulamalardan önemli düzeyde farklllık göstermiş̦tir $(\mathrm{P}<0.05)$. Khakwani ve ark. (2012), altı farklı buğday çeşidi ile yaptıkları çalışmada en yüksek hasat indeksi değerinin $(\% 50,72)$ tarla koşullarındaki kontrol sulamasından elde edilirken, başaklanma dönemine doğru uygulanan 20 günlük kuraklık döneminde yetişen buğdaylarda hasat indeksi değerlerinin \%67 ile \%23 arasında azaldığını bildirmişlerdir. Diğer bir arazi çalışmasında Bayoumi ve ark. (2008) $420 \mathrm{~mm}$ ve 140 mm'lik iki farklı sulama suyu miktarında yetiştirilen buğday çeşitlerine ait ortalama verim değerleri dikkate alındığında, kurak koşullarda bitki boyunda \%14, 7, başak boyunda $\% 23,7$, biyolojik verimde $\% 32,9$, dane veriminde $\% 43,2$, bitki 1000 dane ağırlığında \%16,4 ve hasat indeksi değerinde ise \%12,7'lik azalma olduğunu belirtmişlerdir. Birçok araştırmacı farklı buğday çeşitleri ile kuraklık koşullarında yürüttükleri çalışmalarda, sulu koşullarda yetişen buğday bitkilerinin boy, başak uzunluğu toplam verim, dane verimi ve 1000 dane ağırlıkları ve hasat indeksi değerlerinin kurak koşullarda yetişenlerden istatistiksel olarak önemli düzeyde daha yüksek olduğunu bulmuşlardır (Saleem, 2003; Akram, 2011). Bu çalışmada da benzer şekilde sera koşullarında gelişme dönemi boyunca buğday bitkisine uygulanan toplam sulama suyu miktarı 378 mm'den (\%100 BYS), 286 mm (\%50 BYS) ve 249 mm’ye (\%25 BYS) düştükçe, bitki gelişim parametreleri ve verim değerlerinin de azaldığı bulunmuştur.

Çizelge 2. Bitkiye yarayışlı suyun (BYS) farklı düzeylerinde bitki gelişimi ve verim parametreleri.

\begin{tabular}{lllllll}
\hline $\begin{array}{c}\text { Sulama } \\
\text { uygulamalarl }\end{array}$ & $\begin{array}{c}\text { Bitki } \\
\text { boyu, cm }\end{array}$ & $\begin{array}{c}\text { Başak } \\
\text { boyu, cm }\end{array}$ & $\begin{array}{c}\text { Toplam } \\
\text { biyokütle, } \\
\text { g/saksı }\end{array}$ & $\begin{array}{c}\text { Dane verimi, } \\
\text { g/saksı }\end{array}$ & $\begin{array}{c}\text { 1000 dane } \\
\text { ağırlığl, g }\end{array}$ & $\begin{array}{c}\text { Hasat indeksi, } \\
\%\end{array}$ \\
\hline \%25 BYS & $47,64 \mathrm{c}$ & $7,68 \mathrm{~b}$ & $6,29 \mathrm{c}$ & $3,01 \mathrm{c}$ & $28,83 \mathrm{~b}$ & $45,04 \mathrm{~b}$ \\
$\% 50$ BYS & $52,95 \mathrm{~b}$ & $8,62 \mathrm{a}$ & $8,98 \mathrm{~b}$ & $4,42 \mathrm{~b}$ & $31,06 \mathrm{ab}$ & $49,19 \mathrm{a}$ \\
$\% 100$ BYS & $61,91 \mathrm{a}^{* *}$ & $8,84 \mathrm{a}^{* *}$ & $14,32 \mathrm{a}^{* *}$ & $6,45 \mathrm{a}^{* *}$ & $33,59 \mathrm{a}^{* *}$ & $47,89 \mathrm{a}^{*}$ \\
\hline
\end{tabular}

Farklı harfle gösterilen ortalamalar arasındaki fark ${ }^{* *} \mathrm{P}<0,01$ ve ${ }^{*} \mathrm{P}<0,05$ düzeyinde önemlidir.

\section{Sulama Suyu Miktarının Bitki Su Kullanma Randımanına Etkisi}

Bitkiye yarayışlı su kapasitesinin \%100, \%50 ve \%25 düzeyleri için uygulanan sulama suyu miktarlarına göre hesaplanan su kullanım randımanı (SKR) ve transprasyon oranı değerleri istatistiksel olarak çok önemli düzeyde farklılık göstermiştir ( $\mathrm{P}<0.01$ ) (Şekil 2). Toplam biyokütle ve dane için BYS'un \%100'ünde sırasıyla 1,49 ve 0,67 g/L olarak hesaplanan SKR değerleri, BYS'un \%25'e düșmesiyle en düşük SKR değerleri olarak 
sırasıyla 0,99 ve 0,47 g/L şeklinde bulunmuştur. Toplam biyokütle için hesaplanan SKR değerleri \%100 BYS uygulamasıyla karşılaştırıldığında, \%50 ve \%25 BYS uygulamalarında sırasıyla \%17,3 ve \%33,3 oranlarında azalmıștır. Benzer olarak dane verimine ait SKR değerleri ise \%100 BYS uygulamasına göre \%50 ve \%25 BYS uygulamalarında sırasıyla \%9,1 ve \%28,9 oranlarında azalmıştır. Sivamani ve ark. (2000) serada farklı buğday çeşitleri ile yürüttükleri denemede iyi sulanmış koşullarda bitkilerin SKR değerlerinin 0,66 ile 0,68 $\mathrm{g} / \mathrm{L}$ arasında olduğunu, orta derecede kuraklık koşullarında yetişen bitkilerin 0,53 ile 0,57 g/L arasında belirlenen SKR değerlerinden yüksek olduğunu bildirmişlerdir. Al-Karaki (1998) iki farklı buğday çeşidiyle yürüttüğü sera çalışmasında, iyi sulanan bitkileri su kullanma randımanlarının 0,63 ile 0,78 g kuru madde /L arasında değiştiğini ve kuraklık koşullarında yetişen bitkilerin SKR değerlerinden (0,58 ile 0,65 g/L) daha yüksek bulmuşlardır. Sulama suyu miktarının azalışı transprasyon oranının arttığını göstermiştir (Şekil 2). Su stres koşulları arttıkça birim kuru biyokütle üretimi için bitkinin harcadığı su miktarı artmaktadır. En yüksek transprasyon oranı (1,01 g/L) \%25 BYS uygulamasında belirlenirken, transprasyon oranı değerleri sulama suyunun artışıyla \%50 BYS ( 0,81 L/g) ve \%100 BYS (0,67 L/g) uygulamalarında sirasıyla \%19,7 ve \% 33,5 oranlarında azalmıştır.

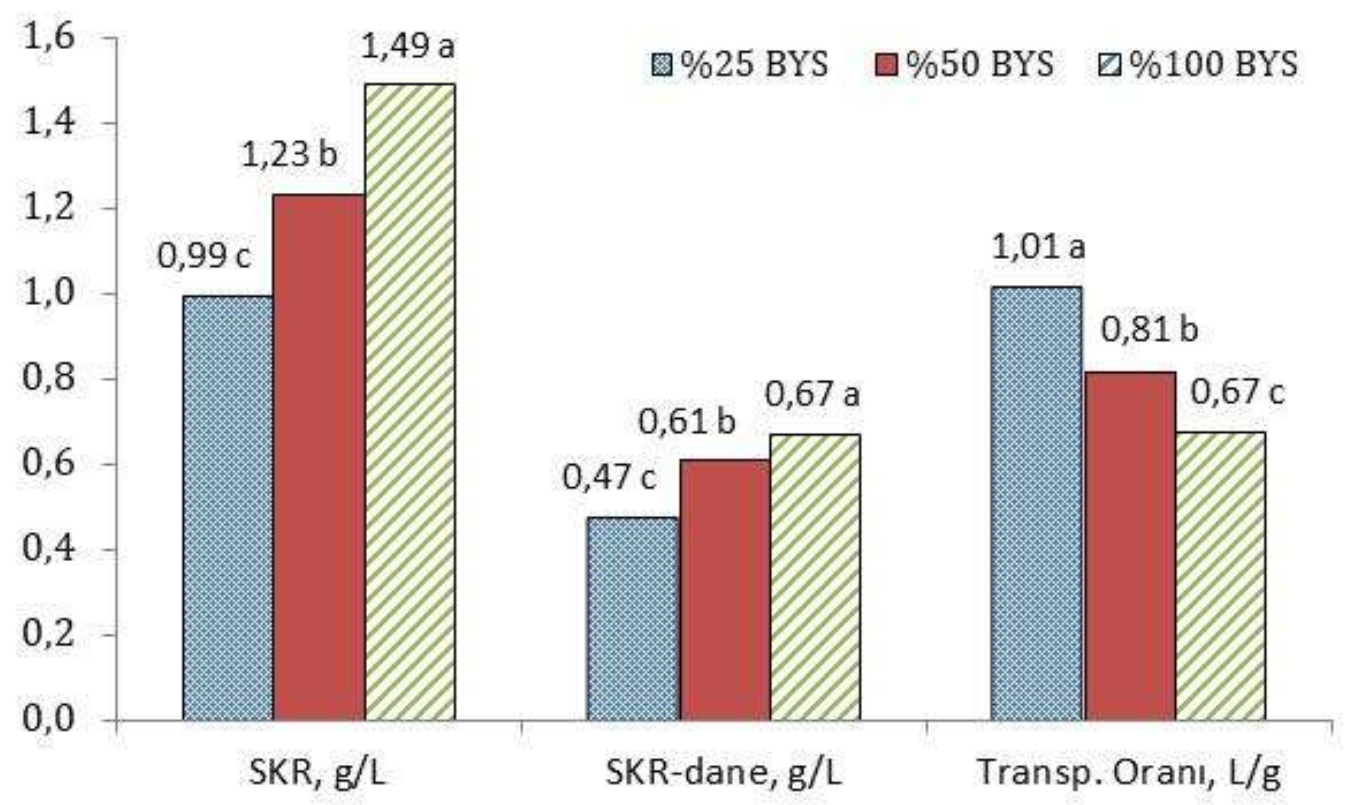

Şekil 2. Bitkiye yarayışlı suyun (BYS) farklı düzeylerinde su kullanma randımanı (SKR) ve transprasyon oranındaki değişimler $(\mathrm{P}<0,01)$.

\section{Sulama Suyu Miktarı, SKR ve Verimlilik Parametreleri Arasındaki İlişkiler}

Bitkiye yarayışlı su kapasitesinin üç farklı düzeyindeki sulama suyu miktarı (SS), SKR, transprasyon oranı ve buğday bitkisine ait verimlilik parametreleri arasındaki korelasyon katsayıları Çizelge 3'te verilmiștir. Sulama suyu miktarı SKR $\left(0,904^{* *}\right)$ ve SRKR-dane $\left(0,841^{* *}\right)$ değerleriyle önemli pozitif, transprasyon oranıyla $\left(-0,878^{* *}\right)$ önemli negatif ilişki göstermiştir. Sulama suyu miktarı ve SKR değerleri verimlilik parametrelerinden toplam biyokütle, dane verimi, 1000 dane ağırlı̆̆, bitki boyu, başak boyu değerleri ile çok önemli pozitif ilişkiler verirken, hasat indeksiyle genelde önemli negatif ilişki göstermişlerdir. Transprasyon oranı ise aynı bitki parametreleriile negatif, hasat indeksi ile pozitif ilişki vermiştir. Buğday bitkisinin toplam biyokütle, dane verimi, bitki boyu ve başak boyu değerleri de kendi arasında çok önemli pozitif ilişkiler vermiştir. Öztürk ve Korkut (2018)'ta farklı kuraklık uygulamalarında yetişen buğday bitkisinin dane verimi, biyolojik verim ve başak uzunluğu değerleri arasında çok önemli pozitif ilişkiler belirlemişlerdir. Khakwani ve ark. (2012), farklı kuraklık koşullarında buğday çeşitleri ile yaptıkları çalışmada bitkilerin yaprak alanları ve nispi nem içerikleri ile bitki boyu, dane verimi, 1000 dane ağırlığı ve toplam biyolojik verim değerleri arasında önemli pozitif korelasyon katsayıları belirlemişlerdir. Bu çalışmada da bitkilerin gelişme dönemi boyunca sağlanan sulama suyu miktarı arttıkça bitkinin verim değerleri de artmıştır. 
Çizelge 3. Sulama suyu miktarı (SS) ile buğday bitkisine ait bazı biyolojik ve fizyolojik parametreler arasındaki ilişkiler $(\mathrm{n}=30)$.

\begin{tabular}{|c|c|c|c|c|c|c|c|c|c|}
\hline & SKR & SKR-dane & $\begin{array}{c}\text { Transpras. } \\
\text { Oranı }\end{array}$ & $\begin{array}{l}\text { Toplam } \\
\text { Biyokütle }\end{array}$ & $\begin{array}{c}\text { Dane } \\
\text { ağırlı̆̆g }\end{array}$ & $\begin{array}{l}1000 \text { dane } \\
\text { ağırlığ }\end{array}$ & $\begin{array}{c}\text { Hasat } \\
\text { Indeksi }\end{array}$ & Bitki Boyu & $\begin{array}{c}\text { Başak } \\
\text { Boyu }\end{array}$ \\
\hline $\mathrm{SS}, \mathrm{mm}$ & $0,904^{* *}$ & $0,841^{* *}$ & $-0,878^{* *}$ & $0,978^{* *}$ & $0,974^{* *}$ & $0,640^{* *}$ & $-0,387^{*}$ & $0,953^{* *}$ & $0,713^{* *}$ \\
\hline SKR & & $0,922^{* *}$ & $-0,985^{* *}$ & $0,970^{* *}$ & $0,950^{* *}$ & $0,522^{* *}$ & $-0,457^{*}$ & $0,868^{* *}$ & $0,686^{* *}$ \\
\hline SKR-dane & & & $-0,935^{* *}$ & $0,887^{* *}$ & $0,936^{* *}$ & $0,621^{* *}$ & $-0,086$ & $0,794^{* *}$ & $0,773^{* *}$ \\
\hline Transp. Oranı & & & & $-0,939^{* *}$ & $-0,932^{* *}$ & $-0,550^{* *}$ & $0,409^{*}$ & $-0,856^{* *}$ & $-0,733^{* *}$ \\
\hline Top. Biyokütle & & & & & $0,984^{* *}$ & $0,586^{* *}$ & $-0,448^{*}$ & $0,928^{* *}$ & $0,693^{* *}$ \\
\hline Dane ağırlı̆̆g & & & & & & $0,653^{* *}$ & $-0,289$ & $0,921^{* *}$ & $0,752^{* *}$ \\
\hline 1000 dane ağ. & & & & & & & 0,051 & $0,676^{* *}$ & $0,416^{*}$ \\
\hline Hasat İndeksi & & & & & & & & $-0,421^{*}$ & $-0,022$ \\
\hline Bitki Boyu & & & & & & & & & $0,690^{* *}$ \\
\hline
\end{tabular}

**\%1 düzeyinde, *\%5 düzeyinde önemli, SS: sulama suyu miktarı, SKR:su kullanma randımanı.

Bitkilerin gelişme dönemi boyunca sağlanan sulama suyu miktarı arttıkça bitkinin verim değerleri de artmıştır. El Hafid ve ark. (1998) farklı kuraklık koşullarında yetiştirilen buğday bitkisinin fotosentez oranı ile dane ve toplam verim değerleri arasında doğrusal ilişkiler elde etmişlerdir. Akram (2011) sulu koşullarda yetişen buğday bitkilerinin ozmotik potansiyellerinin düşmesi ve turgor potansiyellerinin artması nedeniyle fotosentez ve net asimilasyon miktarlarının arttığını ve sonuçta kurak koşullarda yetişen bitkilere göre daha yüksek verim değerleri gösterdiklerini bildirmiştir. Siddique ve ark. (2000) bitki gelişme dönemine bağlı oluşturulan farklı kuraklık koşullarında yetiştirilen buğday çeşitlerinde, bitkilerin su içerikleri, fotosentez ve verim ilişkilerini araştırmışlardır. Araştırmacılar kuraklık koşullarının yaprak su potansiyelini önemli derecede azalttığını, yaprak su içeriğinin azalmasıyla fotosentez oranının azaldığını, kurak koşullarda artan yaprak ve kanopi sıcaklığının stomaların kapanmasına ve solunumun azalmasına neden olabildiğini bildirmişlerdir. El Hafid ve ark. (1998) tam sulama ve üç farklı kuraklık koşulunda yetiştirilen 6 yazlık buğday çeşidi ile yürüttükleri çalışmada, kuraklık koşulları altında toplam kuru madde, dane verimi ve su kullanma randımanı değerlerinin "fotosentez (net $\mathrm{CO}_{2}$ alımı)/solunum oranı (A/E)" ve ozmoregülasyon kapasitesiyle pozitif ilişkiler gösterdiğini bulmuşlardır. Araştırmacılar çeşitlerin kuraklığa dayanımının belirlenmesinde A, A/E, stoma direnci ve ozmotik ayarlama değerlerinin anahtar kontrol noktaları olabileceğini, erken kuraklık koşullarında yüksek ozmoregülasyon kapasitesi ve fotosentez/solunum oranına sahip çeşitlerin seçiminin toplam kuru madde ve dane verimini artırabileceğini belirtmişlerdir. Bu çalışmada da azalan toprak nem miktarlarına bağlı olarak bitkilerin fotosentez ve solunum oranlarının azalmasına bağlı olarak bitkilerin gelişim parametreleri ve verim değerlerinin azaldığı anlaşılmıştır.

\section{Sonuç}

Bitkiye yarayışlı su kapasitesinin \%100, \%50 ve \%25 düzeylerinde yetiştirilen yazlık buğday bitkisinin SKR, gelişme ve verim parametreleri toprak nem içeriğinden önemli düzeyde etkilenmiştir. Sulama suyu miktarının azalmasına bağlı olarak, azalan toprak nemi ve artan su stres koşullarında buğday bitkisinin su kullanma randımanı yani tükettiği birim su miktarı başına ürettiği toplam verim azalmıştır. En yüksek verim ve gelişme parametreleri \%100 BYS nem düzeyinde yetiştirilen bitkilerde belirlenirken, en düşük değerler \%25 BYS uygulamasında belirlenmiştir. Diğer uygulamalar ile karşılaştırıldığında \%100 BYS uygulamasında toprakta daha fazla nemin bulunması stoma direncinin azalmasına ve fotosentezle alınan CO2 miktarının artışına bağlı olarak gelişme ve verim parametrelerinde artış sağladığı anlaşılmıştır. Bitkiye yarayışlı su kapasitesinin \%50 ve \%25 seviyelerinde uygulanmasıyla toprakta azalan nem miktarına bağlı olarak bitkinin turgor durumu azalıp ozmotik potansiyel değeri artmakta, bitki su kaybını önlemek için stomalarını kapatarak solunumunu azaltmaktadır. Bu durum SKR ve net asimilasyonun azalmasıyla verim değerlerinin de azalmasına yol açmaktadır. Sera koşullarında yürütülen bu çalışmada göstermiştir ki toprağın nem içeriği bitki gelişimi için önemli bir edafik faktördür. Eğer toprakta düzensiz yağıș veya kısıtlı sulama uygulamaları sonucunda yeterli nem miktarı bulunmazsa bitkisel verim önemli düzeyde düşecektir.

\section{Kaynaklar}

Akram M, 2011. Growth and yield components of wheat under water stress of different growth stages. Bangladesh Journal of Agricultural Research, 36(3), 455-468.

Al-Karaki GN, Clark RB, 1998. Growth, mineral acquisition, and water use by mycorrhizal wheat grown under water stress. Journal of Plant Nutrition, 21(2), 263-276. 
Arnon I, 1972. Crop Production in Dry Regions, Backgroundand Principles. (Ed.): N. Polunin. Leonard Hill Book, London, Vol. 1, Pp. 203-211.

Austin RB, 1994. Plant breeding opportunities. In: Physiology and Determination of Crop Yield. (Ed.): K.J. Boote. CSSA, Madison, Wisconsin, USA. The American Society of Agronomy. pp. 567-586.

Balkan A, Gençtan T, 2013. Ekmeklik buğdayda (Triticum Aestivum L.) osmatik stresin çimlenme ve erken fide gelişimi üzerine etkisi. Namık Kemal Üniversitesi Tekirdağ Ziraat Fakültesi Dergisi 10(2): 44-52.

Bayoumi TY, Eid MH, Metwali EM, 2008. Application of physiological and biochemical indices as a screening technique for drought tolerance in wheat genotypes. African Journal of Biotechnology 7: 2341-2352.

Blum A, 1993. Selection for sustained production in waterdeficit environments, in: D. Buxton III (Ed.), International Crop Science I, CSSA, Madison, WI, 1993, pp. 343-347.

Budak N, Ylldırım MB, 1995. Harvest index, biomass production and their relationships with grain yield in wheat. Ege Üniversitesi Ziraat Fakültesi Dergisi 32(2), 25-28.

Candemir F, Gülser C, 2011. Effects of different agricultural wastes on some soil quality indexes at clay and loamy sand fields. Communications in Soil Science and Plant Analysis 42(1), 13-28.

Demir Z, Gülser C, 2015. Effects of rice husk compost application on soil quality parameters in greenhouse conditions. Eurasian Journal of Soil Science 4(3), 185-190.

Demiralay İ, 1993. Toprak fiziksel analiz yöntemleri. Atatürk Üniv. Ziraat Fakültesi Yayınları, Erzurum, 111-120.

Dencic S, Kastori R, Kobiljski B, Duggan B, 2000. Evaporation of grain yield and its components in wheat cultivars and land races under near optimal and drought conditions. Euphytica 1: 43-52

El Hafid R, Smith DH, Karrou M, Samir K, 1998. Physiological attributes associated with early-season drought resistance in spring durum wheat cultivars. Canadian Journal of Plant Science 78(2): 227-237.

Gupta NK, Gupta S, Kumar A, 2001. Effect of water stress on physiological attributes and their relationship with growth and yield in wheat cullivars at different growth stages. Journal of Agronomy and Crop Science 186(1), 55-62.

Güler M, 2001.Ekmeklik buğday (Triticum aestivum L.)'ın belirli gelişme dönemlerindeki su stresinin bazı kalite özelliklerine etkisi. Tarım Bilimleri Dergisi 7(3): 21-28.

Gülser C, Kızılkaya R, Aşkın T, Ekberli İ, 2015. Changes in soil quality by compost and hazelnut husk applications in a hazelnut orchard. Compost Science and Utilization 23(3), 135-141.

Kacar B, 1994. Bitki ve Toprağın Kimyasal Anaizleri III. Toprak Analizleri. A.Ü. Zir.Fak. Eğitim Araş. ve Geliştirme Vak. Yay.No:3. Ankara.

Khakwani AA, Dennett MD, Munir M, Abid M, 2012. Growth and yield response of wheat varieties to water stress at booting and anthesis stages of development. Pakistan Journal of Botany 44(3), 879-886.

Majer P, Sass P, Lelley T, Cseuz L, Vass I, Dudits D, Pauk J, 2008. Testing drought tolerance of wheat by a complex stres diagnostic system installed in greenhouse. Acta Biologica Szegediensis 52(1), 97-100.

Maqbool MM, Ali A, Haq T, Majeed MN, Lee DJ, 2015. Response of spring wheat (Triticum aestivum L.) to induced water stress at critical growth stages. Sarhad Journal of Agriculture 31(1), 53-58.

Moustafa MA, Boersma L, Kronstad WE, 1996. Response of four spring wheat cultivars to drought stress. Crop Science 36(4), 982-986.

Öztürk A, 1999. Kuraklığın kışlık buğdayın gelişmesi ve verimine etkisi. Turkish Journal of Agriculture and Forestry 23: 531-540.

Öztürk İ, Korkut KZ, 2018. Ekmeklik buğday (Triticum aestivum L)'ın farklı gelişme dönemlerinde kuraklığın verim ve verim unsurlarına etkisi. Tekirdağ Ziraat Fakültesi Dergisi 15(2), 128-137.

Pan XY, Wang YF, Wang GX, Cao QD, Wang J, 2002. Relationship between growth redundancy and size inequality in spring wheat populations mulched with clear plastic film. Acta Phytoecology Sinica 26: 177-184.

Rajaram S, 2001. Prospects and promise of wheat breeding in 21st century. Euphytica 119: 3-15.

Saleem M, 2003. Response of durum and bread wheat genotypes to drought stress. Asian Journal of Plant Sciences 2(3): 290-293.

Siddique MRB, Hamid A, Islam MS, 2000. Drought stress effects on water relations of wheat. Botanical Bulletin of Academia Sinica 41, 35-39.

Sivamani E, Bahieldin A, Wraith JM, Al-Niemi T, Dyer WE, Ho THD, Qu R, 2000. Improved biomass productivity and water use efficiency under water deficit conditions in transgenic wheat constitutively expressing the barley HVA1 gene. Plant Science,155(1), 1-9.

Soil Survey Staff, 1993. Soil Survey Manuel. USDA Handbook No:18 Washington.

Ünsal NE, Türker MH, Akkaya G, 2018. Bazı durum buğday çeșitlerinin kurağa mukavemet yönünden toprak altı ve üstü organlarının incelenmesi. Harran Tarım ve Gida Bilimleri Dergisi 22(4), 551-559.

Yurtsever N, 1984. Deneysel İstatistik Metotları. Tarım ve Orman Bakanlığı Köy. Hizmetleri Genel Müd. Yayınları 121, 56, 574 s. Ankara. 